\title{
Pulmonary oedema with shock induced by hydrochlorothiazide: a rare side effect mimicking myocardial infarction
}

\author{
Asbjørn Høegholm, Søren W Rasmussen, Kjeld S Kristensen
}

\begin{abstract}
The case of a 68 year old man in whom hydrochlorothiazide induced pulmonary oedema with hypovolaemic shock is presented. The condition was misdiagnosed as myocardial infarction until an early echocardiogram excluded a cardiac cause. The diagnosis was confirmed by an oral challenge.
\end{abstract}

\section{Case report}

A 68 year old man with a previous myocardial infarction was admitted to hospital because of sudden severe dyspnoea, chest tightness, dizziness, and vomiting. He did not recollect taking any drugs. At arrival he was dyspnoeic, cyanotic, and sweating. Blood pressure was 60 $\mathrm{mm} \mathrm{Hg}$ systolic, pulse 85 , and temperature $36 \cdot 2^{\circ} \mathrm{C}$. Fine crepitations were heard bilaterally. Chest $x$ ray indicated pulmonary oedema (figure) and the electrocardiogram showed sinus rhythm with widespread ST depressions. Arterial blood partial pressures were $\mathrm{po}_{2} 6.7 \mathrm{kPa}$ and $\mathrm{pcO}_{2} 3.5 \mathrm{kPa}$ and the $\mathrm{pH}$ was $7 \cdot 33$.

Fibrinolytic treatment was considered but echocardiography showed good contraction of the left ventricle with signs of hypovolaemia. Treatment with albumin and saline was started; central venous pressure rose from 7 to $12 \mathrm{~cm} \mathrm{H}_{2} \mathrm{O}$ and the haematocrit fell from 0.59 to $0 \cdot 47$. Blood pressure became normal within 90 minutes.

In the next few days the electrocardiogram and serum concentrations of creatine kinase were normal whereas low grade fever, leucocytosis, and slight generalised oedema were seen. Chest $x$ ray showed increasing infiltration followed by complete resolution. The patient was discharged but one month later he was readmitted with identical symptoms. This time he remembered taking hydrochlorothiazide $(25$ $\mathrm{mg}$ ) for swollen ankles; earlier he had taken hydrochlorothiazide for two years because of hypertension. He recovered completely on saline alone. No paraprotein was found; eosinophil count, immunoglobulin $\mathrm{E}, \mathrm{Cl}$ esterase inhibitor, radioallergosorbenttest, and histamine liberation from basophils exposed to hydrochlorothiazide were normal. The patient consented to an oral challenge with hydrochlorothiazide $(12.5 \mathrm{mg}$ ) and 30 minutes after this dose symptoms developed.

\section{Discussion}

We found 11 published reports of shock and non-cardiogenic pulmonary oedema associated with hydrochlorothiazide. ${ }^{1-10}$ The full-blown

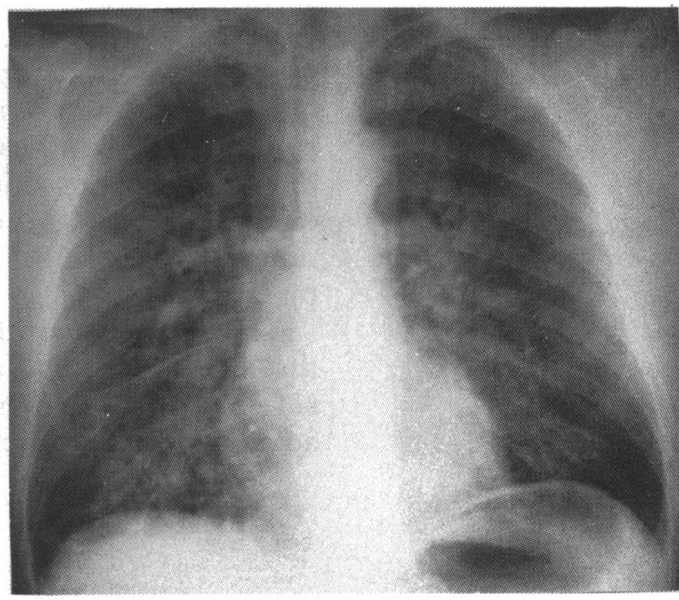

Chest $x$ ray taken on admission showing bilateral pulmonary oedema.

syndrome is only seen when treatment with hydrochlorothiazide is resumed after a long interval. No other thiazide diuretics seem to be incriminated in any of the cases. Our case seems to be the first report of challenge with hydrochlorothiazide as the only active compound; one other case was challenged with a combination of hydrochlorothiazide and triamterene. ${ }^{4}$

An immunological pathogenesis has been suspected but test results have been equivocal; in our case we found no evidence of a classic type 1 mechanism. We regard both the pulmonary changes and hypovolaemia to be caused by extravasation owing to increased capillary permeability as in the systemic capillary leak syndrome, ${ }^{11}$ but with the pulmonary vasculature being more sensitive.

In most cases the syndrome was initially misdiagnosed and one case died. ${ }^{4}$ In our patient echocardiographic examination made prompt and adequate treatment possible.

1 Steinberg AD. Pulmonary edema following ingestion of hydrochlorothiazide. JAMA 1968;204:167-8.

2 Bell RT, Lippmann M. Hydrochlorothiazide-induced pulmonary edema. Arch Intern Med 1979;139:817-9.

3 Gould L, Reddy CVR, Zen B, Singh BK. Life-threatening reaction to thiazides. NY State J Med 1980;80:1975-6.

4 Piper C, Wallem D, Wesche D, Brattig N, Diao GJ, Berg PA. Lungenödem nach Einname von Hydrochlorothiazid. Dtsch Med Wochenschr 1983;108:1480-3.

5 Prupas HM, Brown D. Acute idiosyncratic reaction to hydrochlorothiazide ingestion. West J Med 1983;138: 101-2.

6 Wagner AC. Interstitial pulmonary edema due to hydrochlorothiazide: case report. Va Med J 1983;110:715-6.

7 Parfrey NA, Herlong HF. Pulmonary oedema after hydrochlorothiazide. Br Med J 1984;288:1880.

8 Kounis NG, Nikolaou S, Zavras G, Siablis D. Severe acute interstitial pulmonary edema from Moduretic (amiloride interstitial pulmonary edema from Moduretic (amiloride
plus hydrochlorothiazide). Ann Allergy 1986;57:417-8.

plus hydrochlorothiazide). Ann Allergy 1986;57:417-8.
9 Watrigant Y, Wallaert B, Ramon P, Gosselin B, Peng W, Watrigant Y, Wallaert B, Ramon P, Gosselin B, Peng W,
Tonnel AB. Pneumopathie à l'hydrochlorothiazide Tonnel AB. Pneumopathie à l'hydrochlorothiazid
d'évolution subaiguè. Rev Mal Respir 1986;4:227-9.

10 Caduff F, Gloor HJ. Hydrochlorothiazid-induziertes Lungenödem mit Shock. Schweiz Med Wochenschr 1988; 18:139-42.

Correspondence to Dr Asbjørn Høegholm Medicinsk Afdeling, Naestved, Denmark öfdahl C-G, Sölvell L, Laurell A-B, Johansson BR. Systemic capillary leak syndrome with monoclonal IgG and complement alterations. Acta Med Scand 1979; 